\title{
Understanding Homegarden in Household Food Security Strategy: Case Study Around Jimma, Southwestern Ethiopia
}

\author{
${ }^{1}$ Zerihun Kebebew, ${ }^{2}$ Weyessa Garedew and ${ }^{2}$ Adugna Debela \\ ${ }^{1}$ Department of Natural Resources Management, \\ ${ }^{2}$ Department of Horticulture and Plant Sciences, \\ College of Agriculture and Veterinary Medicine, Jimma University, Jimma, Ethiopia
}

\begin{abstract}
The biophysical and socioeconomic contributions of homegarden agroforestry practices are well appreciated throughout the world. This is particularly more relevant in tropical region as homegardens have been a way of life for century in the region. The present study tries to examine homegarden agroforestry practices and evaluate their significance towards household food security strategy in southwestern Ethiopia. A total of 98 homegardens $(11 \%)$ were randomly selected for the study. A combination of complete plant inventory and interview were used to collect data. The result showed that the size of homegarden ranged from 0.01-1 ha with mean 0.15 ha. About $99 \%$ of the assessed homegarden were established on open areas in response to getting more food and cash to support family. Enset ventricosum, avocado, cabbage, maize, coffee, Catha edulis and banana were the most cultivated crops in the homegarden. The relative household income contribution of homegarden was found about $44.5 \%$. Catha edulis and avocado accounted for about $72.6 \%$ of the homegarden income contribution. Income from homegarden increased an average household income from 2100-3784.11 Ethiopian Birr. A paired $t$ testing result showed that the difference in average annual income of household due to homegarden was significant $(t=8.119, \mathrm{df}=97, \mathrm{p}=0.000)$. The present study revealed that contribution of homegarden goes beyond gap filling. Economic important crops dominated the homegarden. Some households were getting much benefit from their homegardens. Paying due attention to homegarden development has significant role in addressing household food security in the future.
\end{abstract}

Key words: Agroforestry, homegarden, cash crops, livelihood, household income, food security

\section{INTRODUCTION}

Homegardens are traditional agroforestry systems with complex structure and multiple functions (Das and Das, 2005). Smallholder farmers cultivate different crops in the homegarden as a strategy of livelihood diversification which helps to stabilize their sustenance (Abebe et al., 2010). Nair (2008) report indicates that homegarden agroforestry is an age old and time-tested land use approach that makes the best use of nature's goods and services.

These land uses approach have attracted the research attention since late 1970's (Kumar and Nair, 2004; Das and Das, 2005; Nair, 2008). Although, the recorded reports on homegardens are not globally exhaustive (Maroyi, 2009), the biophysical and socioeconomic contributions of homegarden agroforestry practices are well appreciated throughout the world (Mendez, 2001; Kumar and Nair, 2004). This is particularly more relevant in tropical region where homegarden agroforestry practices have been a way of life for century for smallholder farmers (Kumar and
Nair, 2004). To this effect homegarden agroforestry has been considered as one of the best land use option (Kumar, 2006; Akinnifesi et al., 2010) that helped smallholder farmers to support their family (Kalaba et al., 2009).

These homegardens are evolved either through growing food crops in the forests or establishing tree crop production systems on arable lands (Kumar, 2006). Moreover, the homegarden agroforestry systems reflect the wisdom of the traditional culture and ecological knowledge of the local community (Kumar and Nair, 2004; Tangjang and Arunachalam, 2009).

Smallholder farmers in southwestern Ethiopia have an experience of homegarden agroforestry for ages (Bishaw, 2009; Abebe et al., 2010). However, empirical study on homegarden agroforestry practices around Jimma is insufficient. As a result, less attention has been given to homegarden development towards addressing household food security. This study tries to examine homegarden agroforestry practices and evaluate their significance towards household food security strategy.

Corresponding Author: Zerihun Kebebew, Department of Natural Resources Management, 


\section{MATERIALS AND METHODS}

The study site description: The study was conducted at $14 \mathrm{~km}$ from Jimma town. Jimma town is found at $352 \mathrm{~km}$ from Addis Ababa in southwestern Ethiopia. The study site is located between $36^{\circ} 00^{\prime}$ and $37^{\circ} 00^{\prime} \mathrm{N}$ of latitude and $7^{\circ} 00^{\prime}$ and $8^{\circ} 00^{\prime} \mathrm{E}$ of longitude. The area receives annual rainfall between 1200 and $2800 \mathrm{~mm}$. The temperature ranges between 11.8 and $28.8^{\circ} \mathrm{C}$. The altitude of the area is about 2000 m.a.s.l. The total population of the area is about 5440. The total household number of the area is about 888 . The study area has the highest populated density in Jimma zone. Agriculture is the means of the livelihood of the people. Most agricultural producers are subsistence farmers with smallholding. Coffee is the most important cash crop in the area. Maize, teff, sorghum, pulses and root crops are the major crops grown in the area. Perennial crops dominate the homegarden in the area.

Methods: The research was carried out between March-July 2010. A combination of complete plant inventory and interview were used to collect data. Complete plant inventory was done to document plants in homegarden.

Information on household characteristics, purpose of homegarden practices and annual income from homegarden were collected through household interview. Semi structured and structured type of questionnaire was used for the interview. The total number of the households in the study area was 888. From which $98(11 \%)$ homegardens were randomly selected for the study. Data was analyzed using descriptive statistics and paired t-testing. Assumption of normality was checked before running paired t-test. SPSS version 16 was employed for data analysis.

\section{RESULTS AND DISCUSSION}

Household characteristics: The study result showed that the mean family size of the sampled household was 6 . Household that belongs to poor and medium household categories outnumbered the rich household category by $93 \%$. The landholding size of the sampled households ranged from $0.1-7$ ha with mean 1.09 ha. About $62 \%$ of the households owned a land $<1.09$ ha. Household land use categories were identified as homegarden, coffee farm, cultivated land and eucalyptus woodlot. About $45 \%$ of the households owned homegarden, coffee farm, cultivated land and eucalyptus woodlot. About $94 \%$ of the households owned homegarden, coffee farm and cultivated land. The size of homegarden ranged from
Table 1: Summary of household characteristics

\begin{tabular}{lrcccc}
\hline Characteristics & N & Min. & Max. & Mean & Valid percent \\
\hline Family size & 98 & 2.00 & 12 & $\sim 6.00$ & - \\
$\leq 6$ & 68 & - & - & - & 69.4 \\
$>6$ & 30 & - & - & - & 30.6 \\
Wealth status & 98 & - & - & - & - \\
Rich & 6 & - & - & - & 6.7 \\
Medium & 38 & - & - & - & 42.7 \\
Poor & 45 & - & - & - & 50.6 \\
Land holding size (ha) & 98 & 0.10 & 7 & $\sim 1.09$ & - \\
$\leq 1.09$ & - & - & - & - & 62.4 \\
$>1.09$ & - & - & - & - & 37.6 \\
Homegarden area (ha) & 95 & 0.01 & 1 & $\sim 0.15$ & - \\
$\leq 0.15$ & - & - & - & - & 72.6 \\
$>0.15$ & - & - & - & - & 27.4 \\
Household land use categories & 98 & - & - & - & - \\
Homegarden (\%) & - & - & - & - & 100.0 \\
Coffee farm (\%) & - & - & - & - & 93.6 \\
Eucalyptus woodlot (\%) & - & - & - & - & 44.9 \\
Cultivated land (\%) & - & - & - & - & 93.6 \\
\hline
\end{tabular}

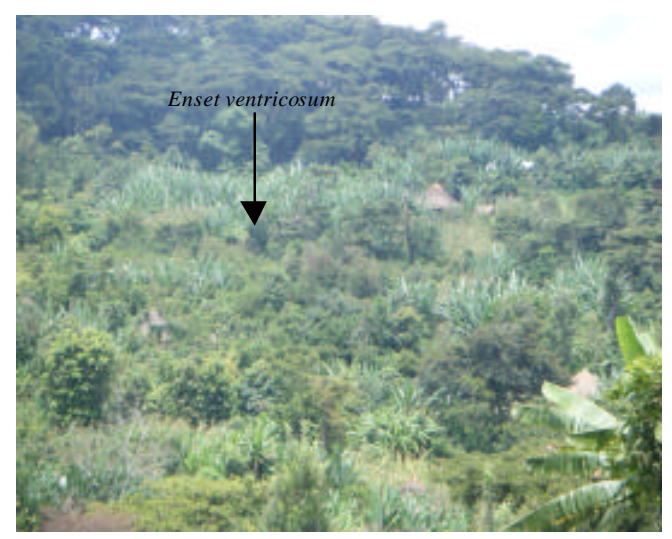

Fig. 1: Partial view of homegarden at study site

0.01-1 ha with mean 0.15 ha. About $73 \%$ of the homegardens sizes were $<0.15$ ha (Table 1). Das and Das (2005) reported homegarden size that ranged from $0.02-1.2$ ha with an average 0.3 ha from Barak valley, India. Kabir and Webb (2009) also reported the land with 0.27 ha used for homestead from southwestern Bangladesh. Tynsong and Tiwari (2010) reported 0.075 ha as average size of homegarden from Meghalaya, India.

Characterization of homegarden: Homegarden in the study area was found quite distinct from other land uses. Homegarden at glance was dominated by Enset ventricosum (Fig. 1). However, the closer the homegarden, the more number of species were seen in the homegarden. Origin and development of homegarden in the study area was found having similar pattern of development and purposes. From 98 selected homegardens, 99\% were established on open areas (cultivated land and grazing land). The intention of the homegarden development was 
Res. J. Applied Sci., 6 (1): 38-43, 2011

Table 2: Categories of homegarden development and their current uses

\begin{tabular}{lccc}
\hline Characteristics & Years & Frequency & Valid percent \\
\hline Duration & & & \\
Minimum & 4 & - & - \\
Maximum & 35 & - & - \\
Categories & & & \\
After 10 y ears & - & 13 & 15.3 \\
Between 10 and 20 & - & 31 & 34.7 \\
Before 20 years & - & 54 & 52.0 \\
Total & - & 98 & 100.0 \\
Homegar den uses & - & & \\
Source of food & - & 11 & 11.2 \\
Source of cash & - & 27 & 27.6 \\
Source of food and cash & - & 60 & 61.2 \\
Total & - & 98 & 100.0 \\
\hline
\end{tabular}

to get more cash and food to support the family. Development of these homegardens was started 35 years ago. About $52 \%$ of the assessed homegardens were developed before 20 years ago. Majority of households $(61.2 \%)$ mentioned homegarden as source of both cash and food (Table 2). This study agrees with Kumar (2006) report that homegardens are evolved through establishing tree crop production systems on arable lands. Homegardens are described based on their structure, composition and arrangement.

Arrangements of the components are deliberate in most homegardens (Mendez et al., 2001). However, investigation on arrangements of the components in the homegarden was found haphazard. There was no specific niche for specific crop was found in the homegarden. As a result, it is difficult to relate component arrangement in the homegarden to practical knowledge of farmers on specific requirement of crops in the homegarden. This is partly explained farmers need more time in accumulating practical knowledge as most of the cultivated crops in the homegarden are exotic species. Table 3 shows the result of plant assessment in 98 homegarden. Complete plant inventory results showed totaling 23 different cultivated crops were identified in homegarden.

The most cultivated crops in the homegarden were Enset ventricosum, avocado, cabbage, maize, coffee, Catha edulis and banana. Enset ventricosum, avocado, cabbage, maize, coffee, Catha edulis and banana were found in $98,92,84,80,78,76$ and $54 \%$ of assessed homegarden, respectively. Usually, these crops were cultivated in the homegarden for consumption and sale. However, the purpose of cultivating specific crop was quite different among households. Majority of the households were cultivating avocado (56.7\%) and Catha edulis $(63.5 \%)$ in the homegarden for sale. Coffee $(58.7 \%)$ and vegetables were cultivated in the homegarden for consumption.

In Sidama southern Ethiopia coffee was cultivated in homegarden for cash (Abebe et al., 2010). However, farmers around Jimma had coffee farm for cash and
Table 3: Plant inventoried, frequency distribution and their purpose of production

\begin{tabular}{|c|c|c|c|c|c|}
\hline \multirow[b]{2}{*}{ Plants } & \multirow{2}{*}{$\begin{array}{c}\text { Frequency } \\
(N=98)\end{array}$} & \multirow{2}{*}{$\begin{array}{l}\text { Cases } \\
(\%)\end{array}$} & \multicolumn{3}{|c|}{ Purpose of production (\%) } \\
\hline & & & Sale & Consumption & Both \\
\hline Avocado & 91 & 92.9 & 56.7 & 10.0 & 33.3 \\
\hline Banana & 53 & 54.1 & 1.8 & 58.2 & 40.0 \\
\hline Wild custard apple & 12 & 12.2 & 8.3 & 75.0 & 16.7 \\
\hline Peach & 4 & 4.1 & Nil & 100.0 & Nil \\
\hline Mango & 14 & 14.3 & Nil & 78.6 & 21.4 \\
\hline Orange & 6 & 6.1 & Nil & 100.0 & Nil \\
\hline Papaya & 11 & 11.2 & Nil & 81.8 & 18.2 \\
\hline Guava & 11 & 11.2 & Nil & 66.7 & 33.3 \\
\hline Apple & 5 & 0.6 & 20 & 40.0 & 40.0 \\
\hline Catha edulis & 75 & 76.5 & 63.5 & 9.5 & 27.0 \\
\hline Enset ventricosum & 96 & 98.0 & 4.4 & 38.3 & 57.4 \\
\hline Coffee & 77 & 78.6 & 8.0 & 58.7 & 33.3 \\
\hline Cabbage & 83 & 84.7 & 1.2 & 87.7 & 11.1 \\
\hline Hot pepper & 20 & 20.4 & Nil & 90.0 & 10.0 \\
\hline Maize & 79 & 80.6 & Nil & 98.7 & 1.3 \\
\hline Onion & 29 & 29.6 & Nil & 89.7 & 10.6 \\
\hline Potato & 3 & 3.1 & Nil & 100.0 & Nil \\
\hline Pulses & 12 & 12.1 & Nil & 92.3 & 7.7 \\
\hline Pumpkin & 17 & 17.3 & Nil & 84.8 & 15.2 \\
\hline Taro & 39 & 39.8 & Nil & 87.5 & 12.5 \\
\hline Sugar cane & 28 & 28.6 & 17.9 & 46.4 & 35.7 \\
\hline Sweet potato & 2 & 2.0 & Nil & 100.0 & Nil \\
\hline Spices & 11 & 11.2 & Nil & 90.0 & 10.0 \\
\hline
\end{tabular}

Table 4: Number of plants species recorded per homegarden and their relative proportion

\begin{tabular}{lrcclc}
\hline $\begin{array}{l}\text { Species number } \\
\text { per homegarden }\end{array}$ & N & Min. & Max. & Mean & Valid percent \\
4 & 1 & 4 & 13 & 8.13 & 1.02 \\
5 & 7 & - & - & - & 7.14 \\
6 & 13 & - & - & - & 13.27 \\
7 & 21 & - & - & - & 21.43 \\
8 & 16 & - & - & - & 16.33 \\
9 & 11 & - & - & - & 11.22 \\
10 & 17 & - & - & - & 17.35 \\
11 & 9 & - & - & - & 9.18 \\
12 & 2 & - & - & - & 2.04 \\
13 & 1 & - & - & - & 1.02 \\
Total & 98 & - & - & - & - \\
\hline
\end{tabular}

usually coffee cultivated at homegarden was used for consumption. Within homegarden the number of species per homegarden ranged from 4-13 where the mean was 8 . About 7 species per homegarden were recorded in most assessed homegardens. About 4 species per homegarden and 13 species per homegarden were not common in most homegardens (Table 4). Previous research on number of species in homegarden varied considerably. For examples, Kabir and Webb (2009) reported 419 species of plants with an average of 34 species per household across 402 homegardens from Bangladesh.

Mendez et al. (2001) reported a total of 324 species with nine different uses from Nicaragua. Tynsong and Tiwari (2010) reported 197 plants species with an average of 89 plant species per homegarden from North-East India on homegarden $750 \mathrm{~m}^{2}$. Abebe et al. (2010) reported 78 cultivated crops within 44 homegardens from Sidama 
Res. J. Applied Sci., 6 (1): 38-43, 2011

Table 5: Cultivated crops in homegarden viz. monthly products distribution

\begin{tabular}{|c|c|c|c|c|c|c|c|c|c|c|c|c|}
\hline Crop type & Sept. & Oct. & Nov. & Dec. & Jan. & Feb. & Mar. & Apr. & May & Jun. & Jul. & Aug. \\
\hline Apple & - & Yes & Yes & - & - & - & - & - & - & - & - & - \\
\hline Avocado & Yes & - & - & Yes & Yes & Yes & Yes & Yes & - & Yes & Yes & Yes \\
\hline Banana & Yes & Yes & Yes & Yes & Yes & Yes & Yes & Yes & Yes & Yes & Yes & Yes \\
\hline Pulses & Yes & Yes & Yes & - & - & - & - & - & - & Yes & Yes & Yes \\
\hline Cabbage & Yes & Yes & Yes & Yes & Yes & - & - & - & - & - & Yes & Yes \\
\hline Catha edulis & Yes & Yes & Yes & Yes & Yes & Yes & Yes & Yes & Yes & Yes & Yes & Yes \\
\hline Peach & - & - & - & - & Yes & Yes & Yes & - & - & - & - & - \\
\hline Coffee & Yes & Yes & Yes & Yes & - & - & - & - & - & - & - & - \\
\hline Pumpkin & Yes & Yes & Yes & Yes & Yes & Yes & - & - & - & Yes & Yes & Yes \\
\hline Enset ventricosum & Yes & Yes & Yes & Yes & Yes & Yes & Yes & Yes & Yes & Yes & Yes & Yes \\
\hline Wild custard apple & Yes & Yes & - & - & - & - & - & - & - & Yes & Yes & Yes \\
\hline Hot pepper & Yes & Yes & Yes & Yes & Yes & - & - & - & - & - & Yes & Yes \\
\hline Maize & Yes & Yes & Yes & - & - & - & - & - & - & - & - & - \\
\hline Mango & - & - & - & Yes & Yes & Yes & Yes & - & - & - & - & - \\
\hline Onion & - & - & - & - & - & - & - & - & - & Yes & Yes & Yes \\
\hline Orange & Yes & Yes & Yes & - & - & - & - & - & - & - & - & - \\
\hline Papaya & Yes & Yes & Yes & Yes & Yes & - & - & Yes & Yes & - & - & - \\
\hline Sugar cane & - & - & Yes & Yes & Yes & Yes & - & - & - & - & - & - \\
\hline Spice & Yes & Yes & Yes & Yes & Yes & Yes & - & - & - & Yes & Yes & Yes \\
\hline sweet potato & - & - & Yes & Yes & Yes & Yes & - & - & - & - & - & - \\
\hline Taro & - & Yes & Yes & Yes & Yes & Yes & - & - & - & - & - & - \\
\hline Guava & Yes & Yes & Yes & Yes & Yes & Yes & - & - & - & - & Yes & Yes \\
\hline \multicolumn{13}{|l|}{ Products types } \\
\hline Minimum & 1 & 1 & 1 & 1 & 1 & 1 & 1 & 1 & 1 & 1 & 1 & 1 \\
\hline Maximum & 7 & 7 & 8 & 6 & 6 & 4 & 4 & 3 & 3 & 5 & 7 & 7 \\
\hline Average & 4 & 4 & $\sim 5$ & $\sim 3$ & $\sim 4$ & $\sim 3$ & $\sim 3$ & 2 & 2 & 3 & 4 & 4 \\
\hline
\end{tabular}

southern Ethiopia with 16 as an average number of species per farm. Olajide-Taiwo et al. (2010) reported 36 planted species in homegarden from Ibdan, Oyo state. Maroyi (2009) reported 69 plant species with 9 different uses from Nhema, Zimbabwe. The total number of species and average number of species per homegarden in the present study was less compared to the previous report. The assessment result shared the same opinion with Abebe et al. (2010) regarding the occurrence of Enset ventricosum in all homegardens.

Olajide-Taiwo et al. (2010) also reported different cultivated crops ranging from fruit trees, vegatbles, spices and food crops in homegarden from Ibadan, Oyo state.

Homegarden to household food security: Assessment of food security status of the household result showed that $88.8 \%$ of the household were found food secured throughout the year. Nevertheless, for $84.5 \%$ of the households $(\mathrm{n}=98)$, the production they produced was sufficient only for 10 months to feed their family. Household food security strategy analysis result showed that smallholder farmers in the study area attained food security through own production and purchasing from local market. In this regard, smallholder farmers in the study area highly appreciated the significance of their homegarden towards attaining food security. About $96.9 \%$ of the households said the impact of homegarden on improving their livelihood was high. Table 5 shows the benefit of homegarden throughout the year. Some of the cultivated crops in the homegarden like Enset ventricosu, cabbage and pulses were critical in July and August in filling shortage of food at household level. Cash obtained from avocado and Catha edulis was found to help household to purchase grain from local market. The study result also showed that there was at least one obtainable product from homegarden throughout the year. The finding agrees with Ndaeyo (2007) report that homestead ensured continuous production and utilization throughout the year. The report strongly indicated that homestead farms are contributing to food security in southern Nigeria. Olajide-Taiwo et al. (2010) also reported homegarden as an easy source of fresh food. The relative household income contribution of homegarden was about $44.5 \%$ (maximum $=14735$, mean $=1683.17$ ) of the total household income. Catha edulis and avocado accounted for about $72.6 \%$ of the homegarden income contribution. About $34.7 \%$ of the total households had an income from homegarden $>1683.17$ Ethiopian birr (Table 6).

Although, household needed more food crops for consumption, maize was the most staple food crops in the study area. On the average $1000 \mathrm{~kg} \mathrm{year}^{-1}$ was calculated as the total quantity of grain required to support an average family size of 6 . Considering the price of maize at the time of assessment, the average income (1683.17 Ethiopian birr) from homegarden enabled households to purchase $935 \mathrm{~kg}$ of maize. Income from homegarden increased an average household income from 2100-3784.11 Ethiopian Birr. A paired t-testing result showed that the difference in average annual income of household due to homegarden was significant $(t=8.119, \mathrm{df}=97, \mathrm{p}=0.000)$. 
Res. J. Applied Sci., 6 (1): 38-43, 2011

Table 6: Household relative income from homegarden, contributor crops and household category

\begin{tabular}{|c|c|c|c|c|c|}
\hline Characteristics & $\mathrm{N}$ & Minimum & Maximum & Mean & Proportion (\%) \\
\hline Household Income (ETB year ${ }^{-1}$ ) & 98 & - & - & - & - \\
\hline Total income & - & 0 & 19000 & 3784.11 & - \\
\hline Inc ome from homegarden & - & 0 & 14735 & 1683.17 & 44.5 \\
\hline Inc ome from homegarden (ETB year ${ }^{-1}$ ) & 98 & 0 & - & 1683.17 & 100.0 \\
\hline Catha edulis & - & 0 & 5340 & 654.18 & 38.9 \\
\hline Avocado & - & 0 & 9735 & 568.05 & 33.7 \\
\hline Others & - & - & 3200 & 460.94 & - \\
\hline (Sugar cane, Enset ventricosum, etc.) & - & - & - & - & 27.4 \\
\hline \multicolumn{6}{|l|}{ Household category } \\
\hline$<$ mean $(1683.18)$ & 64 & - & - & - & 65.3 \\
\hline$\geq$ mean $(1683.18)$ & 34 & - & - & - & 34.7 \\
\hline
\end{tabular}

*ETB = Ethiopian Birr

The present study agrees with many previous researches finding on significance of homegarden to household food security. For examples, Olajide-Taiwo et al. (2010) report from Ibadan, Oyo state showed that homegarding increased family supply. Maroyi (2009) report from Nhema, Zimbabwe indicated homegarden as important for poor households to overcome adversity and meet basic needs. Tynsong and Tiwari (2010) finding from Meghalaya, India showed that homegarden contributed $7 \%$ of the total household income.

Ndaeyo (2007) report from southeastern Nigeria showed the remarkable contribution of homestead farm to food security. Bassullu and Tolunay reported $34.5 \%$ as the share of the income obtained from traditional homegardens in the rural areas of Isparta regions within the annual income. The present finding of the share of income from homegarden $44.5 \%$ within the range of $6.6-55.7 \%$ reported by Soemarwoto (1987) as the share of the income obtained from homegardens in total income.

\section{CONCLUSION}

The present study is the first attempt to conduct study on homegarden in the study area. The foregoing discussions revealed that homegarden of the study area were practiced in response to food security. The contribution of homegarden goes beyond gap filling. Economic important crops dominated the homegarden. Some households were getting much benefit from their homegardens. Paying due attention to homegarden development has significant role in addressing household food security in the future.

\section{ACKNOWLEDGEMENT}

The researcher would like to thank the local community for allowing us to enter their homegarden and also sharing us their precious time for interview. His heartfelt gratitude goes to all who directly or indirectly contributed to realizing the study research.

\section{REFERENCES}

Abebe, T., K.F. Wiersum and F. Bonger, 2010. Spatial and temporal variation in crop diversity in agroforestry homegardens of southern Ethiopia. Agroforest Syst., 78: 309-322.

Akinnifesi, F.K., G. Sileshi, J. da Costa, E.G. de Moura and R.F. da Silva et al., 2010. Floristic composition and canopy structure of home-garden in Sao Luis city, Maranhao state, Brazil. J. Hortic. Forestry, 2: 72-86.

Bishaw, B., 2009. Deforestation and land degradation in the Ethiopian highlands: A strategy for physical recovery. Ee-JRIF, 1: 5-18.

Das, T. and A.K. Das, 2005. Inventorying plant biodiversity in homegardens: A case study in Barak Valley, Assam, North East India. Curr. Sci., 89: 155-163.

Kabir, M.E. and E.L. Webb, 2009. Household and homegarden characteristics in southwestern Bangladesh. Agrofrest Syst., 75: 129-145.

Kalaba, F.K., P.W. Chirwa and H. Prozesky, 2009. The contribution of indigenous fruit trees in sustaining rural livelihoods and conservation of natural resources. J. Hortic. For., 1: 001-006.

Kumar, B.M. and P.K.R. Nair, 2004. The enigma of tropical homegardens. Agroforest. Syst., 61: 135-152.

Kumar, B.M., 2006. Agroforestry: The new old paradigm for Asian food security. J. Trop. Agric., 44: 1-14.

Maroyi, A., 2009. Traditional homegardens and rural livelihoods in Nhema, Zimbabwe: A sustainable agroforestry system. Int. J. Sustainable Dev. World Ecol., 16: 1-8.

Mendez, V.E., 2001. Assessment of Tropical Homegardens as Examples of Sustainable Local Agroforestry Systems. In: Agroecosystem Sustainable: Developing Practical Strategies, Gilessman, S.R. (Ed.). CRC Press, Boca Raton, FL. USA., pp: 51-66.

Mendez, V.E., R. Lok and E. Somarriba, 2001. Interdisciplinary analysis of homegardens in nicaragua: Microzonation, plant use and socioeconomic importance. Agrofor. Syst., 51: 85-96. 
Nair, P.K.R., 2008. Agroecosystem management in the 21 st century: It is time for a paradigm shift. J. Trop. Agric., 46: 1-12.

Ndaeyo, N.U., 2007. Assessing the contribution of homestead farming to food security in a developing economy: A case study of southeastern Nigeria. J. Agric. Soc. Sci., 3: 11-16.

Olajide-Taiwo, F.B., I.B. Adeoye, O. Adebisi-Adelani and O.M.O Odeleye, 2010. Assessment of the benefits and constraints of homegarding in the neighborhood of the national horticulture institute, Ibadan, Oyo state. Am-Eurasian J. Agric. Environ. Sci., 7: 478-483.
Soemarwoto, O., 1987. Homegardens: A Traditional Agrofrestry Systems with a Promising Future. In: Agroforestry: A Decade of Development, Steppler, H.A. and P.K.R. Nair (Eds.). ICRAF, Nairobi, Kenya, pp: $157-172$.

Tangjang, S. and A. Arunachalam, 2009. Role of homegarden systems in Northeast India. Indian J. Traditional knowledge, 8: 47-50.

Tynsong, H. and B.K. Tiwari, 2010. Plant diversity in the homegardens and their significance in the livelihoods of War khasi community of Meghalaya, North-East India. J. Biodiversity, 1: 1-11. 